\title{
PRODUCTION FIELDS AND PHYSIOLOGICAL QUALITY OF PANICUM MAXIMUM JACQ. CV. MOMBASA SEEDS
}

\author{
CAMPOS DE PRODUÇÃO E QUALIDADE FISIOLÓGICA DE SEMENTES DE \\ PANICUM MAXIMUM JACQ. CV. MOMBAÇA
}

\author{
José de Oliveira CRUZ'; Cibele Chalita MARTINS²; Tatiane Sanches JEROMINI²; \\ Givanildo Zildo da Silva ${ }^{3}$ \\ 1. Universidade de Brasília, Faculdade de Agronomia e Medicina Veterinária, Brasília, DF, Brasil. josecruz08@yahoo.com; \\ 2. Universidade Estadual Paulista "Júlio de Mesquita Filho", Departamento de Produção Vegetal, Jaboticabal, SP, Brasil; 3. \\ Universidade Federal de Jataí, Programa de Pós-Graduação em Agronomia, Jataí, GO, Brasil.
}

\begin{abstract}
The physiological quality of seeds is influenced by the climatic factors of production fields. The identification of the best conditions of P. maximum cv. Mombasa production fields allows the improvement of the seed sector. The aim of this work was to identify which climatic conditions of production fields can affect the physiological quality of $P$. maximum cv. Mombasa seeds. Nineteen plots from states of São Paulo (six from municipalities of Auriflama and three from Guzolândia) and Goiás (eight from Quirinópolis and two from Serranópolis), were collected by soil sweeping. The following parameters were evaluated: water content, germination rate, first germination count and germination rate index, seedling emergence in sand and field. Completely randomized design was used for all variables, with the exception of seedling emergence in field, since this variable required block design. Means were compared by the Scott-Knott test, at 5\% probability. For the identification of the influence of climatic conditions on the physiological quality of seeds, multivariate statistical analysis was applied through Group and Principal Component Analysis. Production fields of Panicum maximum cv. Mombasa seeds presenting maximum temperatures above $32{ }^{\circ} \mathrm{C}$ at flowering and natural fall stages produce seeds of low physiological quality. Production fields in which precipitation and high temperatures occur during natural fall and harvest of $P$. maximum cv. Mombasa seeds are not favorable to the production of seeds with high physiological quality.
\end{abstract} Vigor.

KEYWORDS: Climatic conditions. Cumulative precipitation. Forage grass. Multivariate analysis.

\section{INTRODUCTION}

In Brazil, Panicum maximum Jacq., is the second forage grass in importance regarding the volume of marketed seeds (ABRASEM, 2016). Mombasa cultivar is the most productive forage grass, has large size, vigorous tillers, tolerance to drought, adaptability and ease of establishment (CANTO et al., 2012; EUCLIDES et al., 2010; JANK; VALLE; RESENDE, 2011;). These attributes of $P$. maximum cv. Mombasa have increased the expressive demand for its seeds (CANTO et al., 2012).

There are reports of differences in seed lot quality of other forage grasses such as Urochloa decumbens (LAURA et al., 2009), Urochloa brizantha cv. BRS Piata (SILVA et al., 2017) and $U$. brizantha cv. Marandú. (NUNES; BATISTA; NÓBREGA, 2016) due to the climatic conditions of production fields such as temperature, precipitation and relative humidity (SILVA et al., 2017).

Some authors have found that seeds from production fields with low temperatures have better physiological quality than those produced in hot and humid climates (MINUZZI et al., 2010). However, no information was found associating quality of $P$. maximum cv. Mombasa seeds with the climatic conditions of production fields.

For this type of research, the use of multivariate techniques such as Principal Component Analysis (PCA) in data analysis has been shown to be an important tool, since it allows evaluating a large number of lots and different environmental conditions simultaneously (SILVA et al., 2017).

The identification of the conditions that favor production and quality of forage grass seeds allows the recognition of new areas with potential for the implantation of new production fields (MARCOS-FILHO, 2016; SILVA et al., 2019bc;). The selection of the best areas for the production of these seeds enables reducing costs through sectorization logistics, identification of producing areas and production of high-quality seeds (SILVA et al., 2019a). 
There are studies that verify differences in the physiological quality of forage seeds such as $P$. maximum cv. Mombasa (MELO et al., 2016a), cv. Tanzania (MELO et al., 2016b) and U. brizantha cv. BRS Piata (SILVA et al., 2017). The authors verified that the test of seedling emergence in sand and field was efficient to evaluate the physiological quality of lots.

The aim of this study was to verify which climatic conditions of production fields affect the physiological quality of $P$. maximum $\mathrm{cv}$. Mombasa seeds.

\section{MATERIAL AND METHODS}

In this study, 19 P. maximum cv. Mombasa seed lots were evaluated after mechanized harvesting in production fields of different origins from municipalities of Auriflama - SP (lots 1 to 6), Guzolândia - SP (lots 7 to 9), Quirinópolis - GO (lots 10 to 17) and Serranópolis - GO (lots 18 and 19). During seed production, climatic factors such as temperatures (minimum, average and maximum) and cumulative precipitation during flowering, natural fall and harvesting seasons were recorded.

Seeds were harvested using a soil sweeping harvester, in which plants were cut with a cutter blade and a machine put the material together in sheds. The harvester swept the soil mixture from the soil surface along with seeds and removed some of impurities that were mixed with seeds.

Still in the field, the collected material was submitted to a cylindrical sieve machine (typhoon) attached to the tractor power take-off for precleaning. Then, 5-kg homogenized samples from each lot of crude seed were obtained. These were packaged in paper bags and sent to the Laboratory of Seed Analysis of the Faculty of Agrarian and Veterinary Sciences, "Universidade Estadual Paulista", Campus of Jaboticabal - SP, to determine the following quality parameters.

Water content - determined using the method of oven at $105 \pm 3{ }^{\circ} \mathrm{C}$ for 24 hours. Three 2$\mathrm{g}$ seed sub-samples weighted in precision analytical scale were used $(0.001 \mathrm{~g})$ and data were expressed as percentage (wet basis), with one decimal place (BRASIL, 2009).

Germination test - Eight 50-seed subsamples were sown on two paper sheets moistened with 2.5 times their weight in water and packed in transparent plastic boxes with lid $(11.0 \times 11.0 \times 3.5$ $\mathrm{cm})$, under alternating temperature of $20-30{ }^{\circ} \mathrm{C}$ and 8 hour photoperiod (BRASIL, 2009; TOMAZ et al., 2010). Normal seedlings were counted on the $28^{\text {th }}$ day after sowing (BRASIL, 2009). After germination count, the remaining seeds were submitted to the tetrazolium test for the detection of dormant seeds that were counted (TOMAZ et al., 2010).

First germination count - performed together with the germination test by counting normal seedlings present on the seventh day after sowing. Results were presented as percentage (BRASIL, 2009).

Germination rate index - daily counting of germinated seedlings from the seventh to the $28^{\text {th }}$ day after sowing was carried out and the methodology and formula proposed by Maguire (1962) were applied.

Seedling emergence in sand - conducted with four 50-seed sub-samples sown at the depth of $1.0 \mathrm{~cm}$ on sand substrate moistened with water in amount corresponding to $60 \%$ of its retention capacity (BRASIL, 2009) inside plastic boxes of $22.0 \times 15.0 \times 5.0 \mathrm{~cm}$. The test was conducted in greenhouse $\left(25 \pm 2{ }^{\circ} \mathrm{C}\right.$ and $\left.\mathrm{RH}=60 \%\right)$ and, whenever necessary, the substrate was remoistened. At 28 days after sowing, the percentage of emerged seedlings was recorded and results were expressed as percentage (SILVA et al., 2017).

Seedlings emergence in field - the experiment was installed in the experimental area of the Department of Plant Production - UNESP, during the first half of November 2017. Four 50 seed sub-samples were sown at the depth of 1 centimeter in lines of $1.0 \mathrm{~m}$ in length, spaced $0.3 \mathrm{~m}$. The count of emerged seedlings was performed at 28 days after sowing and the result was expressed as percentage (OLIVEIRA et al., 2014). During the test conduction period, the daily maximum and minimum temperatures of the field environment were 17.5 and $36.0{ }^{\circ} \mathrm{C}$, respectively. The mean relative humidity was $75 \%$ and precipitation was $221 \mathrm{~mm}$ distributed over 28 days. Irrigation was carried out whenever necessary.

Statistical procedures - A completely randomized design was used, except for the test of seedling emergence in field, since it had random block design.

Data were previously tested for normality by the Shapiro-Wilk test. Variables germination, first count of seed germination and seedling emergence in sand were transformed into sine arch. Data were then submitted to the Scott-Knott test at $5 \%$ probability.

For the identification of the influence of climatic conditions on the physiological quality of seeds, multivariate statistical analysis was applied, with standardization of variables in average equal to zero and variance equal to one. To obtain similar 
groupings, the hierarchical method was used from the Euclidean distance between lots in the set of variables (SNEATH; SOKAL, 1973). Principal component analysis was based on the Ward groups (HAIR et al., 2005).

\section{RESULTS AND DISCUSSION}

Production fields of $P$. maximum $\mathrm{cv}$. Mombasa seeds presented different climatic conditions, even for some lots produced in fields of the same municipality (Table 1).

Table 1. Minimum (Mi), average (Av) and maximum (Ma) temperatures $\left({ }^{\circ} \mathrm{C}\right)$, cumulative precipitation in mm (P) during flowering, natural fall and harvesting of 19 lots (L) of P. maximum cv. Mombasa seeds of different production fields.

\begin{tabular}{|c|c|c|c|c|c|c|c|c|c|c|c|c|c|}
\hline \multirow{2}{*}{ Municipality } & \multirow{2}{*}{$\mathrm{L}$} & \multicolumn{4}{|c|}{ Flowering } & \multicolumn{4}{|c|}{ Natural fall } & \multicolumn{4}{|c|}{ Harvesting } \\
\hline & & $\mathrm{Mi}$ & $\mathrm{Av}$ & $\mathrm{Ma}$ & $\mathrm{P}$ & $\mathrm{Mi}$ & $\mathrm{Av}$ & $\mathrm{Ma}$ & $\mathrm{P}$ & $\mathrm{Mi}$ & Av & $\mathrm{Ma}$ & $\mathrm{P}$ \\
\hline \multirow{6}{*}{ Auriflama - SP } & 1 & 12 & 25 & 32 & 65 & 13 & 22 & 32 & 15 & 13 & 22 & 29 & 0 \\
\hline & 2 & 11 & 23 & 35 & 76 & 12 & 22 & 33 & 28 & 12 & 21 & 33 & 14 \\
\hline & 3 & 11 & 23 & 34 & 62 & 12 & 22 & 33 & 23 & 12 & 21 & 33 & 50 \\
\hline & 4 & 11 & 22 & 34 & 62 & 12 & 23 & 33 & 23 & 12 & 20 & 33 & 50 \\
\hline & 5 & 11 & 25 & 34 & 25 & 12 & 22 & 33 & 63 & 12 & 22 & 32 & 24 \\
\hline & 6 & 14 & 23 & 31 & 65 & 14 & 22 & 32 & 15 & 13 & 21 & 30 & 0 \\
\hline \multirow{3}{*}{ Guzolândia - SP } & 1 & 13 & 23 & 30 & 108 & 13 & 22 & 30 & 26 & 14 & 20 & 30 & 0 \\
\hline & 2 & 13 & 24 & 29 & 128 & 13 & 22 & 31 & 26 & 13 & 22 & 27 & 0 \\
\hline & 3 & 13 & 23 & 30 & 32 & 14 & 22 & 31 & 8 & 13 & 21 & 28 & 0 \\
\hline \multirow{8}{*}{ Quirinópolis - GO } & 1 & 15 & 24 & 33 & 4 & 12 & 22 & 33 & 19 & 16 & 22 & 32 & 16 \\
\hline & 2 & 15 & 22 & 29 & 15 & 16 & 22 & 31 & 4 & 15 & 23 & 29 & 0 \\
\hline & 3 & 15 & 22 & 32 & 100 & 14 & 22 & 33 & 43 & 17 & 20 & 25 & 14 \\
\hline & 4 & 15 & 22 & 34 & 93 & 14 & 22 & 28 & 49 & 16 & 23 & 30 & 6 \\
\hline & 5 & 15 & 22 & 29 & 15 & 16 & 23 & 31 & 4 & 14 & 22 & 29 & 0 \\
\hline & 6 & 15 & 22 & 34 & 93 & 14 & 22 & 33 & 49 & 16 & 21 & 30 & 6 \\
\hline & 7 & 15 & 24 & 29 & 45 & 16 & 22 & 31 & 4 & 14 & 22 & 29 & 0 \\
\hline & 8 & 15 & 24 & 29 & 49 & 16 & 22 & 31 & 5 & 14 & 22 & 29 & 0 \\
\hline \multirow{2}{*}{ Serranópolis - GO } & 1 & 19 & 23 & 31 & 68 & 15 & 22 & 32 & 6 & 16 & 23 & 30 & 0 \\
\hline & 2 & 17 & 24 & 34 & 98 & 14 & 22 & 33 & 77 & 13 & 22 & 32 & 6 \\
\hline
\end{tabular}

In the vegetative and reproductive growth phases of $P$. maximum cv. Mombasa, minimum temperatures of $11{ }^{\circ} \mathrm{C}$ and maximum temperatures of $35^{\circ} \mathrm{C}$ were registered. The occurrence of frost was not verified in production fields, although there are reports that municipalities of Auriflama - SP $(541 \mathrm{~m})$ and Serranópolis - GO $(718 \mathrm{~m})$ would be susceptible to this event (ASTOLPHO et al., 2004). Frost severely compromises the production of pasture seeds (SOUZA, 2001) and locations subject to this climatic phenomenon should be avoided.

During the flowering phase of plants, temperatures between 11 and $19^{\circ} \mathrm{C}$ and maximum temperatures between 29 and $35^{\circ} \mathrm{C}$ were observed in all production fields. The highest cumulative precipitation of $128 \mathrm{~mm}$ was observed during the flowering of lot 2 from Guzolândia-SP and the lowest in lot 1 from Quirinópolis-GO (4 mm).

Zanuzo, Muller and Miranda (2010) studied the influence of climatic conditions of the flowering season on the quality of $U$. brizantha seeds and verified that the association of high diurnal temperatures and low nocturnal temperatures during seed maturation caused an increase in carbohydrate accumulation, which leads to the formation of seeds with high physiological quality.

In the natural fall phase, temperatures between 12 and $16{ }^{\circ} \mathrm{C}$ and maximum temperatures between 28 and $33{ }^{\circ} \mathrm{C}$ were observed in all production fields. The maximum cumulative precipitation in this phase was $77 \mathrm{~mm}$ during the production of seeds of lot 2 from Serranópolis - GO and the minimum was $4 \mathrm{~mm}$ in lots 2, 5 and 7 from Quirinópolis - GO.

At the harvesting of seed fields, minimum temperatures were between 12 and $17{ }^{\circ} \mathrm{C}$ and maximum temperatures between 25 and $33{ }^{\circ} \mathrm{C}$ were observed. Maximum cumulative precipitation was observed during the harvest of seeds of lots 3 and 4 from Auriflama - SP $(50 \mathrm{~mm})$ and absence of rainfall was observed in the harvest of seeds of lots 1 and 6 from Auriflama - SP; 1, 2 and 3 from 
Guzolândia - SP; 2, 5, 7 and 8 from Quirinópolis GO and 1 from Serranópolis - GO.

The occurrence of precipitations during natural fall and harvesting may lead to deterioration and increase of the incidence of fungi in seeds and also impair the work of harvesting machines (MARCOS-FILHO, 2016; SOUZA, 2001). Thus, in the choice of seed production fields, priority should be given to sites that allow harvesting the field in drought periods (SILVA et al., 2019a).

Table 2 presents the results of the physiological quality analysis of seeds that was also different among lots of production fields.

Table 2. Water content (WC), germination (G), first germination count (FGC), germination rate index (GRI), seedling emergence in sand (SES) and seedling emergence in field (SEF) of 19 lots of P. maximum cv. Mombasa seeds from different regions.

\begin{tabular}{|c|c|c|c|c|c|c|c|}
\hline Procedência & Lots & WC & $\begin{array}{c}G \\
---\%\end{array}$ & FGC & GRI & SES & SEF \\
\hline \multirow{6}{*}{ Auriflama - SP } & 1 & 11 & $79 \mathrm{~b}$ & $79 \mathrm{~b}$ & $4.4 \mathrm{~b}$ & $80 \mathrm{a}$ & $49 \mathrm{a}$ \\
\hline & 2 & 11 & $66 \mathrm{c}$ & $65 \mathrm{c}$ & $3.4 \mathrm{c}$ & $71 \mathrm{a}$ & $40 \mathrm{a}$ \\
\hline & 3 & 10 & $71 \mathrm{c}$ & $70 \mathrm{c}$ & $3.8 \mathrm{c}$ & $74 \mathrm{a}$ & $36 \mathrm{~b}$ \\
\hline & 4 & 12 & $70 \mathrm{c}$ & $70 \mathrm{c}$ & $4.3 \mathrm{~b}$ & $55 \mathrm{~b}$ & $26 \mathrm{c}$ \\
\hline & 5 & 11 & $68 \mathrm{c}$ & $68 \mathrm{c}$ & $3.6 \mathrm{c}$ & $64 \mathrm{~b}$ & $36 \mathrm{~b}$ \\
\hline & 6 & 11 & $92 \mathrm{a}$ & $92 \mathrm{a}$ & $4.9 \mathrm{~b}$ & $85 \mathrm{a}$ & $56 \mathrm{a}$ \\
\hline \multirow{3}{*}{ Guzolândia - SP } & 1 & 11 & $83 \mathrm{~b}$ & $82 \mathrm{~b}$ & $5.0 \mathrm{~b}$ & $74 \mathrm{a}$ & $34 \mathrm{~b}$ \\
\hline & 2 & 11 & $86 \mathrm{~b}$ & $86 \mathrm{a}$ & $4.8 \mathrm{~b}$ & $78 \mathrm{a}$ & $33 \mathrm{~b}$ \\
\hline & 3 & 11 & $96 \mathrm{a}$ & $96 \mathrm{a}$ & $6.0 \mathrm{a}$ & $87 \mathrm{a}$ & $58 \mathrm{a}$ \\
\hline \multirow{8}{*}{ Quirinópolis - GO } & 1 & 10 & $69 \mathrm{c}$ & $69 \mathrm{c}$ & $3.5 \mathrm{c}$ & $78 \mathrm{a}$ & $48 \mathrm{a}$ \\
\hline & 2 & 9,7 & $81 \mathrm{~b}$ & $81 \mathrm{~b}$ & $3.9 \mathrm{c}$ & $73 \mathrm{a}$ & $40 \mathrm{a}$ \\
\hline & 3 & 9,7 & $61 \mathrm{c}$ & $60 \mathrm{c}$ & $2.5 \mathrm{~d}$ & $58 \mathrm{~b}$ & $32 \mathrm{~b}$ \\
\hline & 4 & 9,8 & $70 \mathrm{c}$ & $68 \mathrm{c}$ & $3.3 \mathrm{c}$ & $54 \mathrm{~b}$ & $16 \mathrm{c}$ \\
\hline & 5 & 10 & $89 \mathrm{a}$ & $89 \mathrm{a}$ & $3.7 \mathrm{c}$ & $78 \mathrm{a}$ & $40 \mathrm{a}$ \\
\hline & 6 & 12 & $48 \mathrm{~d}$ & $44 \mathrm{~d}$ & $1.8 \mathrm{~d}$ & $39 \mathrm{c}$ & $19 \mathrm{c}$ \\
\hline & 7 & 11 & $83 \mathrm{~b}$ & $82 \mathrm{~b}$ & $4.2 \mathrm{~b}$ & $85 \mathrm{a}$ & $47 \mathrm{a}$ \\
\hline & 8 & 12 & $83 \mathrm{~b}$ & $83 \mathrm{~b}$ & $4.2 \mathrm{~b}$ & $78 \mathrm{a}$ & $51 \mathrm{a}$ \\
\hline \multirow{2}{*}{ Serranópolis - GO } & 1 & 11 & $83 \mathrm{~b}$ & $83 \mathrm{~b}$ & $3.2 \mathrm{c}$ & $82 \mathrm{a}$ & $44 \mathrm{a}$ \\
\hline & 2 & 9,8 & $76 \mathrm{c}$ & $76 \mathrm{~b}$ & $3.9 \mathrm{c}$ & $67 \mathrm{~b}$ & $25 \mathrm{c}$ \\
\hline $\mathrm{F}$ & - & - & $9.2 * *$ & $8.9^{* *}$ & $8.6^{* *}$ & $11.5^{* *}$ & $5.9^{* *}$ \\
\hline CV (\%) & - & - & 10.2 & 11.0 & 16.5 & 10.4 & 25.3 \\
\hline
\end{tabular}

**Significant at $1 \%$ probability by the $\mathrm{F}$ test. Averages followed by the same letter do not differ from each other by the Scott-Knott test at $5 \%$ probability.

The water content of $P$. maximum cv. Mombasa seeds ranged from 9.7 to $11.7 \%$ among lots (Table 2). Therefore, it was considered uniform, and Silva et al. (2017) recommended differences in water content close to two percentage points for the reliability of results of tests that evaluate the physiological quality of forage grass seeds.

It was possible to observe that seeds from all production fields presented germination rate between 96 and 48\% (Table 2). Thus, all lots under study showed germination rate higher than $40 \%$, according to official standards for the commercialization of $P$. maximum seeds (BRASIL, 2008). However, it should be highlighted that in this work, unprocessed crude seed samples were evaluated. Therefore, quality can still be improved after being submitted to the Seed Processing Unit (UBS) of companies (MELO et al., 2016a).

Seeds of lot 6 from Auriflama - SP; 3 from Guzolândia - SP and 5 from Quirinópolis - GO presented the highest germination rates, 92, 96 and $89 \%$, respectively. Lots 1 from Auriflama - SP; 1 and 2 from Guzolândia - SP; 2, 7 and 8 from Quirinópolis - GO and 1 from Serranópolis - GO, presented germination rates between 79 and $86 \%$, and were the second group of lots regarding germination lower than the first one. The high quality of these lots can be attributed to the absence of rainfall in the period during seed harvesting (Table 1).

Therefore, these results allow inferring that the choice of production fields located in places where the harvesting season of forage grass seeds 
Production fields...

coincides with periods of drought is fundamental to obtain seeds with high physiological quality.

Souza (2001) and Marcos-Filho (2016) stated that rainfall during harvesting causes deterioration of forage grass seeds and causes harvesting delays according to the time required to dry the soil and run the machines.

The lowest germination rate of $48 \%$ was verified in lot 6 from Quirinópolis - GO. The study lots did not contain dormant seeds, only dead (data not shown). A similar fact was found by Melo et al. (2016a) in seeds of the same species and cultivar and has been frequently observed in lots of $P$. maximum seeds, since the sweeping harvest adopted in the last decades favors the natural overcoming of seed dormancy before harvest (TOMAZ et al., 2010).

The first germination count test presented result like germination. Verifying the results of these tests, it was verified that within each municipality, the climatic conditions influenced the physiological quality of seeds. Maximum temperatures above $33{ }^{\circ} \mathrm{C}$ during flowering and natural fall and higher than $30^{\circ} \mathrm{C}$ during harvest possibly reduced seed quality (Table 1).

The germination rate, evaluated by the germination rate index, was only severely affected by unfavorable weather conditions. The lowest indexes were verified for seeds of lots 3 and 6 from Quirinópolis - GO (2.5 and 1.8, respectively); which also presented lower germination rates.

The germination process of seeds with low vigor tends to occur in a slower way (MAGUIRE, 1962; TOMAZ et al., 2010), and lots of seeds with slower germination cause problems to farmers, hampering pasture formation and favoring the emergence of invasive plants (ROCKENBACH et al., 2018).

The seed lots under study presented seedling emergence in sand between 39 and $87 \%$ and these values were higher than those obtained in the standard germination test. The greenhouse temperature, humidity, brightness and substrate disinfection conditions used in tests were more favorable to the germination of seeds, and most plots showed maximum performance, above $71 \%$ seedling emergence in sand.

Seed of lots 4 and 5 from Auriflama - SP; 3 and 4 from Quirinópolis - GO and 2 from Serranópolis - GO presented lower vigor, and the rate of seedling emergence in sand was between 39 and $67 \%$. Lots produced in these production fields were those with lower physiological quality in all other vigor and germination tests.
CRUZ, J. O. et al.

Vigor evaluated by seedling emergence in field was between 16 and 58\%. Despite the low seedling emergence in field when compared with germination results, lots 1, 2, and 6 from Auriflama - SP; lot 3 from Guzolândia - SP; lots 1, 2, 5, 7 and 8 from Quirinópolis - GO and lot 1 from Serranópolis - GO, could be considered of high vigor when evaluated by this variable. In the field, air temperature and precipitation interact with other environmental variables, such as soil fertility, to provide adequate conditions for seed germination and seedling emergence (WALCK et al., 2011).

The greenhouse conditions where the seedling emergence in sand (temperature $25 \pm 2{ }^{\circ} \mathrm{C}$ ) and sowing in sterilized substrate tests were carried out were like the ideal conditions used in the germination test at $20-30{ }^{\circ} \mathrm{C}$ recommended by Brasil (2009). Conversely, the field environment conditions during seedling emergence tests were unfavorable because soil had microorganisms that could damage seeds and the temperature recorded ranged from 17.5 to $36^{\circ} \mathrm{C}$. Therefore, these factors may justify the better performance of seeds in the seedling germination and emergence in sand when compared to results of seedling emergence in field, as was also verified for $P$. maximum cv. Tanzania seeds (MELO et al., 2016b).

Considering all evaluations performed, it was possible to verify that the production field of lot 3 from Guzolândia - SP produced seeds of higher physiological quality and the production field of lot 6 from Quirinópolis - GO, seeds of lower quality.

Even with the separation of lots according to the physiological quality based on variables by the means test, the effect of climatic factors during production on the quality of seeds was evaluated. For this reason, Principal Component Analysis was used, as recommended by Silva et al. (2017).

Due to the large amount of information, it is difficult to elucidate the influence of each of the climatic factors on each seed quality parameter, so it was necessary to analyze the correlation of the principal components (Table 3), as performed by Silva et al. (2017).

Thus, the correlations between principal components and variables germination, first germination count, germination rate index, seedling emergence in sand and field, minimum and maximum temperatures and cumulative precipitation at flowering, natural fall and harvest were initially analyzed (Table 3). The discriminatory power of study variables in each component was analyzed by means of the principal component correlation (HONGYU; SANDANIELO; OLIVEIRA-JUNIOR, 2015). 
Table 3. Correlation of the physiological quality tests and climatic factors of production fields of the 19 lots of P. maximum cv. Mombasa seeds with each principal component.

\begin{tabular}{llcc}
\hline \multirow{2}{*}{ Variables } & & \multicolumn{2}{c}{ Principal components } \\
\cline { 3 - 4 } Quality of seeds & Germination & $\mathbf{0 . 9 1}$ & 2 \\
& First germination count & $\mathbf{0 . 9 0}$ & 0.27 \\
& Germination rate index & $\mathbf{0 . 6 4}$ & 0.30 \\
& Seedling emergence in sand & $\mathbf{0 . 8 3}$ & 0.41 \\
& Seedling emergence in field & $\mathbf{0 . 7 3}$ & 0.43 \\
\hline Fatores climáticos & Minimum temperature at flowering & 0.30 & $\mathbf{- 0 . 7 3}$ \\
& Maximum temperature at flowering & $\mathbf{- 0 . 9 0}$ & 0.21 \\
& Minimum temperature at natural fall & $\mathbf{0 . 6 3}$ & $\mathbf{- 0 . 6 3}$ \\
& Maximum temperature at natural fall & -0.50 & 0.32 \\
& Minimum temperature at harvest & 0.24 & $\mathbf{- 0 . 8 0}$ \\
& Maximum temperature at harvest & -0.50 & $\mathbf{0 . 6 0}$ \\
& Cumulative precipitation at flowering & -0.32 & -0.21 \\
& Cumulative precipitation at natural fall & $\mathbf{- 0 . 7 4}$ & -0.14 \\
Eigenvalues & Cumulative precipitation at harvest & $\mathbf{- 0 . 6 5}$ & 0.50 \\
Total variance $(\%)$ & & 6.21 & 3.18 \\
Accumulated variance & $(\%)$ & 44.33 & 22.71 \\
\hline
\end{tabular}

Note: Variables indicated in bold have significant importance for the factor.

In order to explain the variability of data in the principal component analysis, two components with variance of $44.33 \%$ in $\mathrm{PC} 1$ and $22.71 \%$ in $\mathrm{PC} 2$ were required (Table 3). The cumulative variance was $67.04 \%$. This value was sufficient to explain the variables analyzed, since the cumulative variance should be approximately 70\% (RENCHER, 2002; SILVA et al., 2017).

In each principal component, the correlation values should be equal to or greater than 0.6 to be considered relevant and discriminatory (LORENTZ; NUNES, 2013; SILVA et al., 2017). Thus, in the correlation analysis, all variables were able to explain data with reliability, except for maximum temperature in natural fall and cumulative precipitation in flowering, which did not have discriminatory power in at least one of the two principal components. The germination rate and the minimum temperature in natural fall presented correlation in the two principal components studied.

In the correlation analysis of principal component 1 , it was verified that all variables that evaluated the physiological quality of seeds such as germination (0.91), first germination count $(0.90)$, germination rate index (0.64), seedling emergence in sand (0.83) and in field (0.73) and climatic factors of maximum temperature at flowering ($0.90)$, minimum temperature at natural fall (0.63), cumulative precipitation at natural fall $(-0.74)$ and harvest (-0.65), presented discriminatory power (Table 3).
In principal component 1, physiological quality variables of seed lots were inversely proportional to climatic conditions of maximum temperature at flowering, cumulative precipitation at natural fall and harvesting. This phenomenon can be verified by positive and negative numerical values.

According to the correlation analysis of principal components, it was verified that the higher the maximum temperature at flowering, the lower the physiological quality of $P$. maximum cv. Mombasa seeds, according to the positive and negative values of table 3 , confirming data observed in the comparison of means of table 2 and climatic data of table 1 .

Therefore, production fields that showed during flowering maximum temperatures above 32 ${ }^{\circ} \mathrm{C}$ (Table 1) produced seeds with lower physiological quality. This fact was verified in the analysis of germination test, first germination count and germination rate index results (Table 2). In addition, fields where precipitation was observed during harvesting (Table 1), produced seeds with low physiological quality, also verified by previously mentioned tests (Table 2).

Still in this component, the minimum temperature at natural fall presented behavior similar to the physiological quality, i.e., as the minimum temperature increased, there was an increase in germination and vigor (first count and germination rate index), as verified in the positive correlation values (Table 3 ). 
Thus, production fields with minimum temperatures lower than $13{ }^{\circ} \mathrm{C}$ and $15{ }^{\circ} \mathrm{C}$ during natural fall (Table 1) of seed lots from the states of São Paulo and Goiás, respectively, produced seeds with low physiological quality, when evaluated by germination and first germination count tests (Table 2). Nery et al. (2012) reported that production fields in which high temperatures and humidity occur during natural fall and harvesting produced higher quality forage grass seeds, but in lower amounts.

In principal component 2, among physiological quality variables, only germination rate index (0.61) presented discriminatory power. Climatic factors that presented this power were minimum temperature at flowering (-0.73), minimum temperature at natural fall $(-0.63)$ and maximum temperature at harvest $(0.60)$ (Table 3$)$.

Among the variables arranged in the dispersion plane, the most representative in principal component 1 were germination, first germination count and maximum temperature at flowering, as they had the highest eigenvectors in the dispersion plane (Figure 1) and the highest discriminatory power, with correlation of \pm 0.90 (Table 3 ). In principal component 2, only minimum temperature at harvest had higher eigenvector in the dispersion plane (Figure 1) and greater discriminatory power (correlation of \pm 0.80 ).

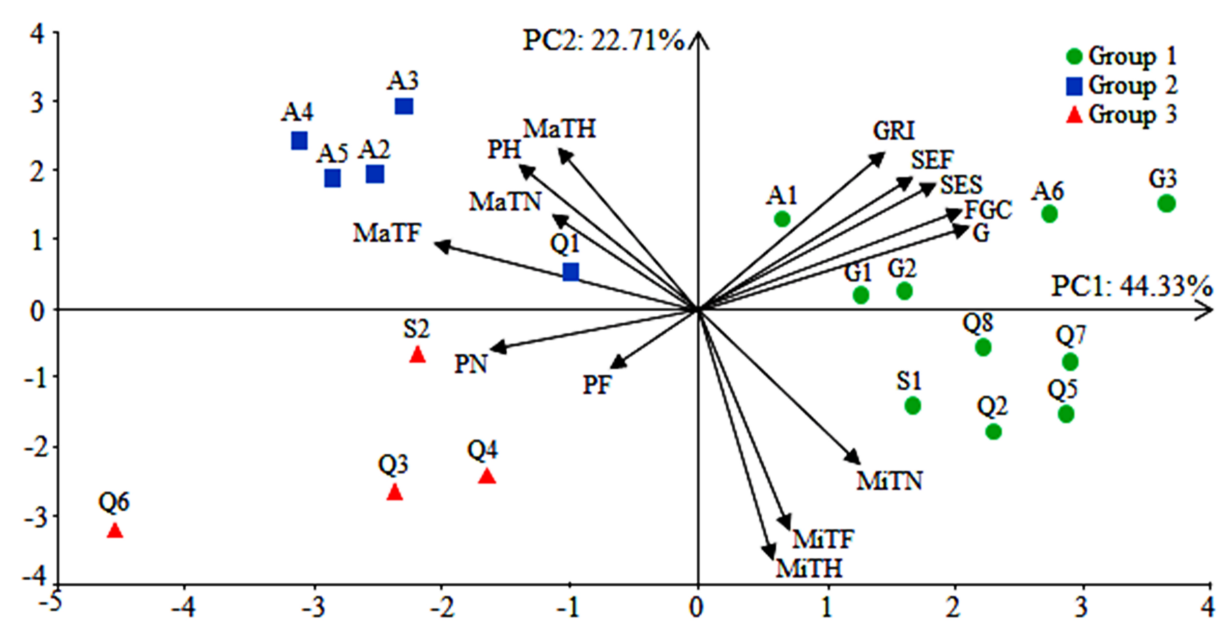

Figure 1. Biplot-type dispersion plane with circle of eigenvectors obtained by the analysis of two principal components (PC1 and PC2) established based on variables germination $(\mathrm{G})$, first germination count (FGC), germination rate index (GRI), seedling emergence in sand (SES), seedling emergence in field (SEF), minimum temperature at flowering (MiTF), natural fall (MiTN) and harvest (MiTH), maximum temperature at flowering (MaTF), natural fall (MaTN) and harvest $(\mathrm{MaTH})$, cumulative precipitation at flowering $(\mathrm{PF})$ natural fall $(\mathrm{PN})$ and harvest $(\mathrm{PH})$ in the evaluation of the physiological quality of 19 lots of $P$. maximum cv. Mombasa seeds.

*Lots identification: A1 to A6 (Auriflama - SP); G1 to G3 (Guzolândia - SP); Q1 to Q8 (Quirinópolis - GO); S1 and S2 (Serranópolis - GO).

In the dispersion graph, the distribution of lots forming three distinct groups was verified (Figure 1). Group 1 consisted of lots 1 and 6 from Auriflama - SP; 1, 2 and 3 from Guzolândia - SP; 2, 5, 7 and 8 from Quirinópolis - GO and lot 1 from Serranópolis - GO. These fields produced seeds with the highest physiological quality indicated by germination eigenvectors, first count and germination rate index, seedling emergence in sand and field closer to these lots. The production fields of these lots also presented low cumulative precipitation at the time of seed natural fall, as verified by the eigenvector that indicates this phenomenon in the opposite quadrant. Therefore, production fields with cumulative precipitation less than $26 \mathrm{~mm}$ at the time of natural fall did not have the physiological quality of seeds. Minimum temperatures below $13{ }^{\circ} \mathrm{C}$ at natural fall and harvest of production fields harmed the physiological quality of seeds produced according to germination and vigor tests.

Group 2 was composed of lots 2, 3, 4 and 5 from Auriflama - SP and lot 1 from Quirinópolis GO. This group of lots presented lower quality seeds compared to those of the previous group, indicated by the distance of physiological quality eigenvectors (germination, first count and germination rate index, seedling emergence in sand and field). At the production sites of these lots, maximum temperatures above $33{ }^{\circ} \mathrm{C}$ were recorded during flowering. At harvest, maximum temperatures were higher than $31^{\circ} \mathrm{C}$ and cumulative 
Production fields...

precipitation above $14 \mathrm{~mm}$. This fact can be verified by the presence of eigenvectors in the same quadrant of lots of the dispersion plane of figure 1 and according to climatic data of table 1.

In this group, it could be verified in almost all plots of this group, minimum temperatures of 11 and $12{ }^{\circ} \mathrm{C}$ occurred in production fields during flowering, natural fall and harvest, according to eigenvectors located in the opposite quadrant (Figure 1) and data from table 1.

Group 3 was formed by the seed production fields of lots 3, 4 and 6 from Quirinópolis - GO and 2 from Serranópolis - GO. These seed lots presented low physiological quality. The presence of germination eigenvectors and vigor tests in the quadrant opposite to lots allowed inferring that there was low affinity between these production fields and the quality of seeds produced. Possibly, high temperatures and high cumulative precipitations during natural fall and harvesting of seeds produced in these fields have reduced their quality. High precipitation during natural fall of forage grass seeds may affect their quality, as it may cause seeds still in formation to fall (SOUZA, 2001).
CRUZ, J. O. et al.

Thus, it was observed that climatic factors such as minimum and maximum temperatures and cumulative precipitation during the production stages of $P$. maximum cv. Mombasa affected the physiological quality of seeds.

\section{CONCLUSIONS}

Production fields of $P$. maximum cv. Mombasa seeds showing maximum temperatures above $32{ }^{\circ} \mathrm{C}$ at flowering and natural fall stages produce seeds of low physiological quality;

Production fields in which precipitations and high temperatures occur during natural fall and harvest of $P$. maximum cv. Mombasa seeds are not favorable to the production of seeds with high physiological quality.

\section{ACKNOWLEDGMENTS}

This study was financed in part by the Coordenação de Aperfeiçoamento de Pessoal de Nível Superior - Brasil (CAPES) - Finance Code 001.

RESUMO: A qualidade fisiológica das sementes é influenciada pelos fatores climáticas dos campos de produção. A identificação das condições dos melhores campos de produção de $P$. maximum cv. Mombaça permite aprimoramento do setor de sementes. O objetivo desse trabalho foi identificar quais condições climáticas dos campos de produção podem afetar a qualidade fisiológica das sementes de $P$. maximum cv. Mombaça. Foram avaliados dezenove lotes procedentes do estado de São Paulo (seis de Auriflama e três de Guzolândia) e Goiás (oito de Quirinópolis e dois de Serranópolis), colhidos por varredura do solo. Foram avaliados por meio dos seguintes parâmetros: teor de água, germinação, primeira contagem de germinação e índice de velocidade de germinação, emergência de plântulas em areia e em campo. Adotou-se delineamento inteiramente casualizado para todas as variáveis, com exceção da emergência de plântulas em campo, pois neste adotou-se delineamento em blocos. As médias foram comparadas pelo teste Scott-Knott, a 5\% de probabilidade. Para a identificação da influência das condições climáticas na qualidade fisiológica das sementes aplicou-se análise estatística multivariada por meio de Análise de Agrupamento e Componentes Principais. Campos de produção de sementes de Panicum maximum cv. Mombaça que apresentam temperaturas máximas superiores a $32{ }^{\circ} \mathrm{C}$ nas épocas de florescimento e degrana produzem sementes de baixa qualidade fisiológica. Campos de produção em que ocorram precipitações e altas temperaturas durante a degrana e à colheita de sementes de $P$. maximum cv. Mombaça não são favoráveis a produção de sementes com alta qualidade fisiológica.

PALAVRAS-CHAVE: Análise multivariada. Condições climáticas. Gramínea forrageira. Precipitação acumulada. Vigor.

\section{REFERENCES}

ABRASEM. Anuário 2016. Brasília: ABRASEM, 2016. 126 p.

ASTOLPHO, F.; CAMARGO, M. B. P.; PEDRO JUNIOR, M. J.; PALLONE FILHO, W. J. Probabilidade de ocorrência de geadas no Estado de São Paulo. O Agronômico, Campinas, v. 56, n. 1, p. 10-11, 2004. 
BRASIL. Ministério da Agricultura, Pecuária e do Abastecimento Gabinete do Ministro. Instrução Normativa $\mathrm{n}^{\mathrm{o}}$ 30, de 21 de maio de 2008. Publicado no Diário Oficial da União, Poder Executivo, 23 de maio de 2008, Seção 1, p. 45.

BRASIL. Ministério da Agricultura, Pecuária e Abastecimento. Regras para análise de sementes. Brasília: MAPA/ACS, 2009. 399 p.

CANTO, M. W.; NETO, A. B.; JÚNIOR, E. J. P.; GASPARINO, E.; BOLETA, V. S. Produção e qualidade de sementes do capim-mombaça em função da adubação nitrogenada. Bragantia, Campinas, v. 71, n. 3, p. 430 437, 2012. http://dx.doi.org/10.1590/S0006-87052012005000032.

EUCLIDES, V. P. B.; VALLE, C. B.; MACEDO, M. C. M.; ALMEIDA, R. G.; MONTAGNER, D.B.; BARBOSA, R.A. Brazilian scientific progress in pasture research during the first decade of XXI century.

Revista Brasileira de Zootecnia, v. 39, [s.n.], p. 151-168, 2010 (supl. especial).

http://dx.doi.org/10.1590/S1516-35982010001300018.

HAIR, J. F.; ANDERSON, R. E.; TATHAM, R. L.; BLACK, W. C. Análise multivariada de dados. 5. ed. Porto Alegre: Bookman, 2005. 593 p.

HONGYU, K.; SANDANIELO, V. L. M.; OLIVEIRA-JUNIOR, G. J. Análise de componentes principais: resumo teórico, aplicação e interpretação. Engineering and Science, Cuiabá, v. 15, n. 1, p. 83-90, 2015. http://dx.doi.org/10.18607/ES201653398.

JANK, L.; VALLE, C. B.; RESENDE, R. M. S. Breeding tropical forages. Crop Breeding and Applied Biotechnology, Viçosa, v.1, n. esp. p.27-34. 2011. http://dx.doi.org/10.1590/S1984-70332011000500005.

LAURA, V. A.; RODRIGUES, A. P. D’A. C.; ARIAS, E. R. A.; CHERMOUTHT, K. S.; ROSSI, T. Qualidade física e fisiológica de sementes de braquiárias comercializadas em Campo Grande - MS. Ciência e Agrotecnologia, Lavras, v. 33, n. 1, p. 326-332, 2009. http://doi.org/10.1590/S141370542009000100045.

LORENTZ, L. H.; NUNES, U. R. Relações entre medidas de qualidade de lotes de sementes de arroz. Revista Ciência Agronômica, Fortaleza, v. 44, n. 4, p. 798-804, 2013. http://dx.doi.org/10.1590/S180666902013000400017.

MAGUIRE, J. D. Speed of germination aid in selection and evaluation for seedling and vigour. Crop Science, Madison, v. 2, n. 2, p. 176-177, 1962. https://doi.org/10.2135/cropsci1962.0011183X000200020033x

MARCOS-FILHO, J. Seed physiology of cultivated plants. Londrina: ABRATES, 2016. 617 p.

MELO, L. F.; MARTINS, C. C.; SILVA, G. Z.; BONETI, J. E. B.; VIEIRA, R. D. Beneficiamento na qualidade física e fisiológica de sementes de capim-mombaça. Revista Ciência Agronômica, Fortaleza, v. 47, n. 4, p. 667-674, 2016a. http://doi.org/10.5935/1806-6690.20160080.

MELO, L. F.; MARTINS, C. C.; SILVA, G. Z.; SANCHES, M. F. G. Processing in the quality of tanzania grass seeds. Engenharia Agrícola, Jaboticabal, v. 36, n. 6, p. 1157-1166, 2016b. http://dx.doi.org/10.1590/18094430-eng.agric.v36n6p1157-1166/2016.

MINUZZI, A.; BRACCINI, A. L.; RANGEL, M. A. S.; SCAPIM, C. A.; BARBOSA, M. C.; ALBRECHT, A. P. Qualidade de sementes de quatro cultivares de soja, colhidas em dois locais no estado do mato grosso do sul. Revista Brasileira de Sementes, Londrina, v. 32, n. 1 p. 176-185, 2010. http://dx.doi.org/10.1590/S010131222010000100020 . 
NERY, M. C. NERY, F. C.; SILVA, D. R. G.; SOARES, F. P. Produção de sementes forrageiras. Universidade Federal de Lavras, Departamento de Ciência do Solo. Editora UFLA, Boletim Técnico, n. 88, 2012. 47p. http://www.editora.ufla.br/index.php/component/phocadownload/category/10boletins?download=1013: boletins.

NUNES, J. V. D.; BATISTA, V. T.; NÓBREGA, L. H. P. Qualidade fisiológica de sementes de Brachiaria brizantha cv. Marandu com variação nas características de pureza. Revista de Agricultura, Piracicaba, v. 91, n. 1, p. 92-100, 2016. http://www.fealq.org.br/ojs/index.php/revistadeagricultura/article/view/228. https://doi.org/10.37856/bja.v91i1.228

OLIVEIRA, S. S. C.; MARTINS, C. C.; CRUZ, J. S.; SILVA, J. C. Seleção de progênies de nabo forrageiro para germinação sob altas temperaturas. Ciência Rural, Santa Maria, v. 44, n. 2, p. 217-222, 2014. http://dx.doi.org/10.1590/S0103-84782014000200004.

RENCHER, A. C. Methods of Multivariate Analysis. 2. ed. A JOHN WILEY \& SONS, INC. PUBLICATION. 2002. 727 p. https://doi.org/10.1002/0471271357

ROCKENBACH, A. P.; RIZZARDI, M. A.; NUNES, A. L.; BIANCHI, M. A.; CAVERZAN, A.; SCHNEIDER, T. Interferência entre plantas daninhas e a cultura: alterações no metabolismo secundário. Revista Brasileira de Herbicidas, Londrina, v. 17, n. 1, p. 59-70, 2018. https://doi.org/10.7824/rbh.v17i1.527.

SILVA, G. Z.; MARTINS, C. C.; CRUZ, J. O.; JEROMINI, T. S.; BRUNO, R. L. A. Evaluation the physiological quality of Brachiaria brizantha cv. BRS 'Piatã' seeds. Bioscience Journal, Uberlândia, v. 33, n. 3, p. 572-580, 2017. http://dx.doi.org/10.14393/BJ-v33n3-36519.

SILVA, G. Z.; MARTINS, C. C.; CRUZ, J. O.; JEROMINI, T. S. ; MACHADO, C. G. Production regions and physical quality of Urochloa decumbens cv. Basilisk seeds. Bioscience Journal, Uberlândia, v. 35, n.1, p. 236243, 2019a. https://doi.org/10.14393/BJ-v35n1a2019-41749.

SILVA, G. Z.; MARTINS, C. C.; JEROMINI, T. S.; PEREIRA, E. C. B.; BRUNO, R. L. A. Production regions, physical and physiological quality of Brachiaria brizantha cv. BRS 'Piatã' seeds. Revista Ciência

Agronômica, Fortaleza, v. 50, n. 4, p. 552-561, 2019b. http://dx.doi.org/10.5935/1806-6690.20190065.

SILVA, G. Z.; MARTINS, C. C.; NASCIMENTO, L. C.; BARRETO, G. G.; FARIAS, O. R. Phytosanitary quality of Brachiaria brizantha 'BRS Piatã' seeds in function of climate conditions. Revista Brasileira de Engenharia Agrícola e Ambiental, Campina Grande, v. 23, n. 4, p. 237-243, 2019c.

http://dx.doi.org/10.1590/1807-1929/agriambi.v23n4p237-243.

SNEATH, P. H. A.; SOKAL, R. R. Numerical taxonomy. San Francisco: W. H. Freeman, 1973. 573 p.

SOUZA, F. H. D. Produção de sementes de gramíneas forrageiras tropicais. São Carlos: EMBRAPA, 2001. $43 \mathrm{p}$.

TOMAZ, C. A.; MARTINS, C. C.; CARVALHO, L. R.; NAKAGAWA, J. Duração do teste de germinação do capim-tanzânia. Revista Brasileira de Sementes, Londrina, v. 32, n. 4, p. 80-87, 2010. http://dx.doi.org/10.1590/S0101-31222010000400009.

WALCK, J.; HIDAYAT, I. S.; DIXON, K.W.; THOMPSON, K.; POSCHLOD, P. Climate change and plant regeneration from seed. Global Change Biology, Oxford, v. 17, n. 1. p. 2145-2161, 2011.

https://doi.org/10.1111/j.1365-2486.2010.02368.x.

ZANUZO, M. R.; MULLER, D.; MIRANDA D. M. Análise de sementes de capim braquiária (Brachiaria brizantha cv. Marandú) em diferentes épocas de florescimento. Uniciências, Cuiabá, v. 14, n. 2, p. 187-197, 2010. http://dx.doi.org/10.17921/1415-5141.2010v14n2p\%25p. 